\title{
Lithocholic acid: a new emergent protector of intestinal calcium absorption under oxidant conditions
}

\author{
Ana M. Marchionatti, Adriana Pérez, María A. Rivoira, Valeria A. Rodríguez, \\ and Nori G. Tolosa de Talamoni
}

\begin{abstract}
LCA and $1,25(\mathrm{OH})_{2} \mathrm{D}_{3}$ are vitamin D receptor ligands with different binding affinity. The secosteroid stimulates intestinal $\mathrm{Ca}^{2+}$ absorption. Whether LCA alters this process remains unknown. The aim of our work was to determine the effect of LCA on intestinal $\mathrm{Ca}^{2+}$ absorption in the absence or presence of NaDOC, bile acid that inhibits the cation transport. The data show that LCA by itself did not alter intestinal $\mathrm{Ca}^{2+}$ absorption, but prevented the inhibitory effect of NaDOC. The concomitant administration of LCA avoided the reduction of intestinal alkaline phosphatase activity caused by NaDOC. In addition, LCA blocked a decrease caused by NaDOC on gene and protein expression of molecules involved in the transcellular pathway of intestinal $\mathrm{Ca}^{2+}$ absorption. The oxidative stress and apoptosis triggered by NaDOC were abrogated by LCA co-treatment. In conclusion, LCA placed in the intestinal lumen protects intestinal $\mathrm{Ca}^{2+}$ absorption against the inhibitory effects caused by NaDOC. LCA avoids the reduction of the transcellular $\mathrm{Ca}^{2+}$ movement, apparently by blocking the oxidative stress and apoptosis triggered by $\mathrm{NaDOC}$, normalizing the gene and protein expression of molecules involved in $\mathrm{Ca}^{2+}$ movement. Therefore, LCA might become a possible treatment to improve intestinal calcium absorption under oxidant conditions.
\end{abstract}

Key words: NaDOC, LCA, intestinal $\mathrm{Ca}^{2+}$ absorption, oxidative stress, apoptosis.

Résumé : L'acide lithocholique (ALC) et la $1,25(\mathrm{OH})_{2} \mathrm{D}_{3}$ sont des ligands du récepteur de la vitamine $\mathrm{D}$ possédant des affinités de liaisons différentes. Le sécostéroïde stimule l'absorption intestinale de $\mathrm{Ca}^{2+}$. On ignore encore comme l'ALC modifie ce processus. Les auteurs avaient pour objectif de connaître l'effet de l'ALC sur l'absorption intestinale du $\mathrm{Ca}^{2+}$ en absence ou en présence de déoxycholate de sodium (NaDOC), un acide biliaire que inhibe le transport des cations. Les données montrent que l'ALC seul ne modifiait pas l'absorption intestinale de $\mathrm{Ca}^{2+}$ mais il prévenait l'effet inhibiteur du NaDOC. L'administration concomitante d'ALC prévenait la réduction de l'activité de la phosphatase alcaline intestinale causée par le NaDOC. De plus, l'ALC bloquait une diminution provoquée par le NaDOC de l'expression génique et protéique de molécules impliquées dans la voie transcellulaire d'absorption intestinale de $\mathrm{Ca}^{2+}$. Le stress oxydant et l'apoptose déclenchés par le NaDOC étaient abolis par un co-traitement à l'ALC. En conclusion, l'ALC situé dans la lumière intestinale protège l'absorption intestinale de $\mathrm{Ca}^{2+}$ des effets inhibiteurs du NaDOC. L'ALC empêche la réduction du mouvement transcellulaire de $\mathrm{Ca}^{2+}$ apparemment en bloquant le stress oxydant et l'apoptose déclenchés par le NaDOC, normalisant l'expression génique et protéique de molécules impliquées dans le mouvement de $\mathrm{Ca}^{2+}$. Ainsi, l'ALC pourrait devenir un traitement pour améliorer l'absorption intestinale de $\mathrm{Ca}^{2+}$ en conditions oxydantes. [Traduit par la Rédaction]

Mots-clés : NaDOC, ALC, absorption intestinale de $\mathrm{Ca}^{2+}$, stress oxydant, apoptose.

\section{Introduction}

BAs are important molecules involved in the intestinal absorption of lipids and fat-soluble vitamins. BAs are also recognized as regulatory molecules. They can activate specific nuclear receptors and cell signaling pathways in a physiological manner. BAs regulate their own synthesis and other biosynthetic and metabolic pathways during the feed-fast cycle. In addition, these molecules also have the potential to control cell proliferation and inflammatory processes either in the liver or in the gastrointestinal tract (Hylemon et al. 2009). Cholic and chenodeoxycholic acids are the major primary BAs synthesized in the liver. In the intestine, they are deconjugated and $7 \alpha$-dehydroxylated by anaerobic microflora to secondary BAs. They are mainly converted into deoxycholic acid (DCA) and lithocholic acid (LCA) (Masubuchi et al. 2016). BAs exhibit distinct biological effects, depending on the chemical configuration, degree of hydrophobicity, receptors which they bind to, concentration, or other physiological conditions.

The biological properties of LCA and its derivatives have been extensively studied. It has been shown that LCA binds to VDR (Makishima et al. 2002), has antibacterial activity (do Nascimento et al. 2015), produces antiproliferative and pro-apoptotic effects on human cancer cell lines (Schneider et al. 1996; Halvorsen et al. 2000), inhibits proteasome (Dang et al. 2011), acts as a membrane

Received 9 August 2016. Accepted 23 September 2016.

Abbreviations: BAs, bile acids; CB, calbindin $\mathrm{D}_{28 \mathrm{k}}$; DAB, 3,3'-diaminobenzidine; DCA, deoxycholic acid; FXR, farnesoid X receptor; LCA, lithocholic acid; NaDOC, sodium deoxycholate; NBT, nitro blue tetrazolium; $\mathrm{NCX} 1$, sodium-calcium exchanger; $\cdot \mathrm{O}_{2}^{-}$, superoxide anion; PMCA, plasma membrane calcium ATPase; PXR, pregnane X receptor; RIPA, radio immunoprecipitation assay buffer; RT, reverse transcriptase; UDCA, ursodeoxycholic acid; VDR, vitamin D receptor.

A.M. Marchionatti, A. Pérez, M.A. Rivoira, V.A. Rodríguez, and N.G. Tolosa de Talamoni. Laboratorio "Dr. Fernando Cañas", Cátedra de Bioquímica y Biología Molecular, Facultad de Ciencias Médicas, INICSA (CONICET-Universidad Nacional de Córdoba), Pabellón Argentina, 2do. Piso, Ciudad Universitaria, 5000 Córdoba, Argentina.

Corresponding author: Nori G. Tolosa de Talamoni (email: ntolosatalamoni@yahoo.com.ar).

Copyright remains with the author(s) or their institution(s). Permission for reuse (free in most cases) can be obtained from RightsLink. 
pore (Banerjee et al. 1993), and has anti-aging properties (Arlia-Ciommo et al. 2014). So far, the effect of LCA on intestinal $\mathrm{Ca}^{2+}$ absorption has not been reported. This is remarkable considering that $1,25(\mathrm{OH})_{2} \mathrm{D}_{3}$ is recognized worldwide as the main stimulator of intestinal $\mathrm{Ca}^{2+}$ absorption, and both LCA and $1,25(\mathrm{OH})_{2} \mathrm{D}_{3}$ are VDR ligands, although they have different VDR binding affinity (Ishizawa et al. 2008).

We have demonstrated that intestinal $\mathrm{Ca}^{2+}$ absorption is modulated by BAs. Our studies have shown that the sodium deoxycholate (NaDOC) and the ursodeoxycholic acid (UDCA) have differential effects on intestinal $\mathrm{Ca}^{2+}$ absorption. NaDOC inhibits $\mathrm{Ca}^{2+}$ transport across the intestine by triggering oxidative stress and apoptosis (Rivoira et al. 2012). In contrast, UDCA increases intestinal $\mathrm{Ca}^{2+}$ absorption, which seems to be mediated by VDR, leading to enhancement of protein and gene expressions of molecules involved in the $\mathrm{Ca}^{2+}$ transcellular pathway. The combination of NaDOC and UDCA neutralizes both responses, probably because UDCA protects the intestine against the glutathione depletion and the protein carbonyl increment produced by NaDOC (Rodríguez et al. 2013). Recently, we have shown that the inhibitory and stimulatory effects of NaDOC and UDCA on intestinal $\mathrm{Ca}^{2+}$ absorption occur by decreasing or increasing the $\mathrm{Ca}^{2+}$ uptake by mature enterocytes, respectively. Moreover, we have demonstrated that UDCA normalizes the $\mathrm{Ca}^{2+}$ transcellular pathway acting as an anti-apoptotic and anti-autophagic agent (Rodríguez et al. 2016).

Since LCA is a VDR ligand, it is possible that LCA could also stimulate intestinal $\mathrm{Ca}^{2+}$ absorption. To determine this, we have studied the effects of LCA on intestinal $\mathrm{Ca}^{2+}$ absorption in the absence and presence of NaDOC. Our work also provides insights into the underlying mechanisms involved in the response of the intestine to LCA alone or in combination with NaDOC.

\section{Material and methods}

\section{Chemicals}

All reagents were purchased from Sigma-Aldrich (St. Louis, Missouri, USA) unless otherwise stated.

\section{Animals}

One-day old Cobb Harding chicks (Gallus gallus domesticus) were obtained from Indacor S.A. (Rio Ceballos, Córdoba, Argentina) and were fed a normal commercial avian diet (Cargill, S.A.C.I., Pilar, Córdoba, Argentina). At 4 weeks of age, they were distributed among 4 groups: (i) controls, (ii) chicks treated with $1 \mathrm{~mL}$ of $10 \mathrm{mmol} / \mathrm{L} \mathrm{NaDOC}$, (iii) chicks treated with $1 \mathrm{~mL}$ of $0.2 \mathrm{mmol} / \mathrm{L} \mathrm{LCA}$, and (iv) chicks treated with $0.5 \mathrm{~mL}$ of $10 \mathrm{mmol} / \mathrm{L} \mathrm{NaDOC}$ and $0.5 \mathrm{~mL}$ of $0.2 \mathrm{mmol} / \mathrm{L}$ LCA at the same time. Chicks were laparotomized under anesthesia $(50 \mathrm{mg}$ ketamine/ $\mathrm{kg}$ body mass (b.m.) and $10 \mathrm{mg}$ xylazine $/ \mathrm{kg} \mathrm{b.m}$.) and a $10 \mathrm{~cm}$ segment of the duodenum was ligated, as previously described (Tolosa de Talamoni et al. 1996). One milliliter of phosphate buffer saline (PBS, vehicle), NaDOC, LCA, or NaDOC + LCA was injected into the distal portion of the sac, and the loop was reintroduced in the abdomen for $30 \mathrm{~min}$. All experimental protocols followed the Guide for the Care and Use of Laboratory Animals from the Medicine School of the Universidad Nacional de Córdoba, Córdoba, Argentina. All efforts were made to minimize the number of animals used and their suffering. They were killed by cervical dislocation, and the excised duodena were rinsed with cold $0.15 \mathrm{~mol} / \mathrm{L} \mathrm{NaCl}$, and mucosa, enterocytes, or intestinal mitochondria were isolated, as described below.

\section{Intestinal $\mathrm{Ca}^{2+}$ absorption}

After injecting each BA or vehicle in the duodenal lumen for $30 \mathrm{~min}$ and rinsing the intestinal segment with saline solution, $1 \mathrm{~mL}$ of $150 \mathrm{mmol} / \mathrm{L} \mathrm{NaCl}$ and $1 \mathrm{mmol} / \mathrm{L} \mathrm{CaCl}$, containing $1.85 \times$ $105 \mathrm{~Bq}^{45} \mathrm{Ca}^{2+}$ (pH 7.2) was introduced into the lumen of the ligated intestinal segment. After $0.5 \mathrm{~h}$, blood was withdrawn by cardiac puncture, centrifuged, and the plasma ${ }^{45} \mathrm{Ca}^{2+}$ was measured in a liquid scintillation counter. Absorption was defined as appearance of ${ }^{45} \mathrm{Ca}^{2+}$ in the blood (Marchionatti et al. 2001).

\section{Enzyme assays}

Intestinal alkaline phosphatase (AP) (EC 3.1.3.1) activity was assayed in supernates from duodenum homogenates, as previously reported (Marchionatti et al. 2001). Caspase-3 (Cas-3) activity (EC 3.4.22.56) was accomplished in the supernatant from the homogenates of enterocytes following the absorbance of $p$-nitroaniline obtained from a caspase-3-substrate I (Calbiochem, San Diego, California, USA) in a plate reader at $405 \mathrm{~nm}$ (Garcia-Calvo et al. 1998).

\section{Superoxide anion and protein carbonyl contents}

Superoxide anion $\cdot \mathrm{O}_{2}^{-}$measurements were accomplished in mature enterocytes from the duodenal villus tip, which were isolated as previously described (Centeno et al. 2004). Cellular viability was assayed by the trypan blue exclusion technique. Cells were washed twice with Hanks buffer $(137 \mathrm{mmol} / \mathrm{L} \mathrm{NaCl}, 5.4 \mathrm{mmol} / \mathrm{L} \mathrm{KCl}, 0.25 \mathrm{mmol} / \mathrm{L}$ $\mathrm{Na}_{2} \mathrm{HPO}_{4}, 0.44 \mathrm{mmol} / \mathrm{L} \mathrm{KH}_{2} \mathrm{PO}_{4}, 1.3 \mathrm{mmol} / \mathrm{L} \mathrm{CaCl} 2,1 \mathrm{mmol} / \mathrm{L} \mathrm{MgSO}_{4}$, $4.2 \mathrm{mmol} / \mathrm{L} \mathrm{NaHCO}_{3}, 6.24 \mathrm{mmol} / \mathrm{L}$ glucose; $\mathrm{pH}$ 7.4) and incubated with NBT $(1 \mathrm{mg} / \mathrm{mL})$ at $37^{\circ} \mathrm{C}$ for $1 \mathrm{~h}$. The formazan precipitates formed were dissolved in dimethylsulfoxide (DMSO) and quantified at $560 \mathrm{~nm}$. OD values are direct indicators of $\cdot \mathrm{O}_{2}^{-}$concentration in the samples (Serrander et al. 2007). The protein carbonyl content was determined by using 2,4-dinitrophenylhydrazine in an aliquot from homogenates of scraped duodenal mucosa diluted in an isolation buffer ( $50.3 \mathrm{mmol} / \mathrm{L}$ HEPES, $127 \mathrm{mmol} / \mathrm{L} \mathrm{KCl}, 1.36 \mathrm{mmol} / \mathrm{L}$ EDTA, $0.5 \mathrm{mmol} / \mathrm{L} \mathrm{MgSO}_{4}$, and $0.183 \mathrm{mmol} / \mathrm{L} \mathrm{PMSF}, \mathrm{pH} \mathrm{7.4)}$ ) following the procedure of Levine et al. (1990).

\section{RNA isolation and analysis of gene expression by quantitative RT-PCR}

Total RNA isolation from duodenal mucosa was performed with TRIZOL reagent according to the manufacturer's instructions (Invitrogen, Carlsbad, Calif.). RNA concentration and purity were determined by spectrophotometry. Quantitative RT-PCR amplification was performed in a thermocycler (Quantitative PCR thermocycler Stratagene Mx 3000P; Agilent Technologies, Inc., Santa Clara, Calif.). Amplification mixture (total volume $25 \mu \mathrm{L}$ ) contained $0.5 \mu \mathrm{g}$ RNA, $0.3 \mu \mathrm{mol} / \mathrm{L}$ each primer, $0.4 \mu \mathrm{L}$ of the diluted reference dye, $1.0 \mu \mathrm{L}$ of RT/RNase block enzyme mixture, and $12.5 \mu \mathrm{L}$ of 2X Brilliant II SYBR Green QRT-PCR master mix (Stratagene, Agilent Technologies). The following protocol was used: 1 cycle at $50{ }^{\circ} \mathrm{C}$ for $30 \mathrm{~min}, 1$ cycle at $95{ }^{\circ} \mathrm{C}$ for $10 \mathrm{~min}, 40$ cycles as follows: denaturation at $95{ }^{\circ} \mathrm{C}$ for $30 \mathrm{~s}$, annealing at $55{ }^{\circ} \mathrm{C}$ for $60 \mathrm{~s}$, and extension at $72{ }^{\circ} \mathrm{C}$ for $30 \mathrm{~s}$. The amount of PCR products formed in each cycle was evaluated on the basis of SYBR Green fluorescence. Primer sequences for amplification of chick sodium calcium exchanger 1 (NCX1) gene were as follows: forward 5'-GACTGTTTC CAACCTCACAC-3' and reverse 5'-TAGCAACCTTTC CGTCCATC-3', which amplified a $490 \mathrm{bp}$ fragment. Primers sequences for chick plasma membrane calcium ATPase $\left(P M C A 1_{b}\right)$ gene were: forward 5'-GTTGTGCAGATAATTATGCTGC-3' and reverse 5'-GGAATTTCAA GCGGCTAGTTGG-3', which amplify a 120 bp long sequence. Primers sequences for chick calbindin $\mathrm{D}_{28 \mathrm{k}}\left(C B D_{28 k}\right)$ gene were: forward 5'-ATGGATGGGAAGGAGCTACAA-3' and reverse 5'-TGGCACCTA AAGA ACAACAGGAAAT-3', which amplify a 194 bp long sequence. Cycle-to-cycle fluorescence emission readings were monitored and quantified using the $\Delta \Delta C_{T}$ method (Livak and Schmittgen 2001). The copy numbers of mRNA from each gene was normalized relative to that of $18 \mathrm{~S}$.

\section{Western blot analysis}

Immunoblotting analysis of NCX1, PMCA 1 b $, C B D_{28 k}, F A S$, and FASL was performed using mucosal homogenates from the chick duodenum. Suspensions were done in RIPA (radio immuno precipitation assay buffer) lysis buffer (1\% SDS, $0.5 \%$ sodium deoxycholate in 
PBS, containing $1 \mathrm{mmol} / \mathrm{L}$ PMSF, and $1 \mathrm{mmol} / \mathrm{L} \mathrm{NaF})$, and then centrifuged. Afterwards, proteins $(100 \mu \mathrm{g})$ were denatured for $5 \mathrm{~min}$ at $95^{\circ} \mathrm{C}$ and separated in $12 \%(w / v)$ SDS-polyacrylamide minigels for FAS, FASL, and CB $\mathrm{D}_{28 \mathrm{k}}$, and in $8 \%(w / v)$ SDS-polyacrylamide minigels for the other proteins (Laemmli 1970). Gels containing the separated proteins were immersed in the transfer buffer $(25 \mathrm{mmol} / \mathrm{L}$ Tris-HCl, $192 \mathrm{mmol} / \mathrm{L}$ glycine, $0.05 \% w / v$ SDS, and 20\% $v / v$ methanol) (Towbin et al. 1979). Nitrocellulose membranes $(0.45 \mu \mathrm{m})$ were blocked for $1.5 \mathrm{~h}$ with $2 \% w / v$ nonfat dry milk in $0.5 \mathrm{~mol} / \mathrm{L}$ Tris-buffered saline solution and incubated overnight at $4{ }^{\circ} \mathrm{C}$ with the specific primary antibody at 1:1000 dilution in each case. The antibodies were: anti-NCX 1 monoclonal antibody PPS019 (R\&D Systems, Minneapolis, Minnesota, USA), anti-PMCA ${ }_{1 \mathrm{~b}}$ (human erythrocyte clone 5F10 A7952 Sigma-Aldrich), anti-CB $D_{28 k}$ (anti CB $D_{28 k}$, polyclonal antibody produced in rabbit, Sigma-Aldrich), mouse anti-CD95 (FAS) monoclonal antibody (BD Pharmigen Biosciences, San José, Calif.), and rabbit anti-FASL polyclonal antibody (Santa Cruz Biotechnology, Santa Cruz, Calif.). After 3 washings, appropriate secondary biotinylated antibodies were incubated at room temperature for $1 \mathrm{~h}$. Then, the blots were washed 3 times and streptavidin-biotin conjugate (Histostain-SP Broad Spectrum, Invitrogen Calif.) was added. Detection was performed using 3,3'diaminobenzidine (DAB) as the chromogen. Monoclonal antibody anti-GAPDH (clone GAPDH-71.1, Sigma-Aldrich) was used to detect GAPDH as a marker to normalize the relative expression of the other proteins. The band intensities were quantified using an Image Capturer EC3 Imaging System, Launch VisionWorks LS (Life Science, Cambridge, UK) software to obtain the relative expression of proteins.

\section{Changes in mitochondrial membrane permeability (swelling) \\ Isolation of the mitochondria \\ Mitochondria were isolated from duodenal mucosa of the con-} trol animals by differential centrifugation, as previously reported (Tolosa de Talamoni et al. 1985). Isolated intestinal mitochondria (3 mg protein) were incubated in $3 \mathrm{~mL}$ of respiratory buffer ( $0.1 \mathrm{~mol} / \mathrm{L} \mathrm{NaCl}, 10 \mathrm{mmol} / \mathrm{L}$ MOPS, $1 \mathrm{mmol} / \mathrm{L}$ glutamate, $1 \mathrm{mmol} / \mathrm{L}$ malate; pH 7.4) for $10 \mathrm{~min}$ at $25^{\circ} \mathrm{C}$, and monitored at $540 \mathrm{~nm}$ in a Beckman Coulter DU640 spectrophotometer (USA). Basal values of mitochondrial absorbance were measured for $5 \mathrm{~min}$, and the optical density was followed for 5 more minutes, after addition of NaDOC $(1 \mathrm{mmol} / \mathrm{L})$, LCA $(0.2 \mathrm{mmol} / \mathrm{L})$, or NaDOC + LCA $(1 \mathrm{mmol} / \mathrm{L}$ and $0.2 \mathrm{mmol} / \mathrm{L}$, respectively) (Rodrigues et al. 1998).

\section{Statistics}

Data are the mean \pm SE. Results were evaluated by 1-way analysis of variance (ANOVA) and the Bonferroni post-hoc test. Differences were considered statistically significant at $p<0.05$. All the analyses were carried out by using SPSS software (version 22.0) for Windows 8.1 (SPSS, Inc., Chicago, Illinois, USA).

\section{Results}

LCA did not alter the intestinal $\mathrm{Ca}^{2+}$ absorption but prevented the inhibitory effect of NaDOC

As previously observed, NaDOC inhibited the chick intestinal $\mathrm{Ca}^{2+}$ absorption. In contrast, LCA did not modify this physiological process, but it prevented the inhibition caused by NaDOC when both BAs were administered simultaneously (Fig. 1).

\section{The concomitant administration of LCA avoided the} reduction of intestinal AP activity caused by NaDOC

Figure 2 shows that the effects of NaDOC and (or) LCA on intestinal AP activity were similar to that of the intestinal $\mathrm{Ca}^{2+}$ absorption. In other words, NaDOC produced a decrease in the enzyme activity, LCA did not change it, and NaDOC plus LCA neutralized the NaDOC effect.
Fig. 1. Effect of different treatments on chick intestinal $\mathrm{Ca}^{2+}$ absorption. After injecting $0.2 \mathrm{mmol} / \mathrm{L} \mathrm{LCA}, 10 \mathrm{mmol} / \mathrm{L} \mathrm{NaDOC}$, $0.2 \mathrm{mmol} / \mathrm{L} \mathrm{LCA}+10 \mathrm{mmol} / \mathrm{L} \mathrm{NaDOC}$, or vehicle in the duodenal lumen for $30 \mathrm{~min}$ and rinsing the intestinal segment, $1 \mathrm{~mL}$ of $150 \mathrm{mmol} / \mathrm{L} \mathrm{NaCl}$ and $1 \mathrm{mmol} / \mathrm{L} \mathrm{CaCl}_{2}$, containing $1.85 \times 10^{5} \mathrm{~Bq}^{45} \mathrm{Ca}^{2+}$ ( $\mathrm{pH}$ 7.2), was introduced into the lumen of the ligated intestinal segment for $30 \mathrm{~min}$. Then, blood was withdrawn by cardiac puncture, centrifuged, and the plasma ${ }^{45} \mathrm{Ca}^{2+}$ was measured. Values are the mean \pm SE: Control ( $n=7$ chicks); NaDOC ( $n=5$ chicks); LCA ( $n=6$ chicks); NaDOC + LCA ( $n=7$ chicks); ${ }^{*}, p<0.05$ compared with the control, LCA, and NaDOC + LCA treatment groups.

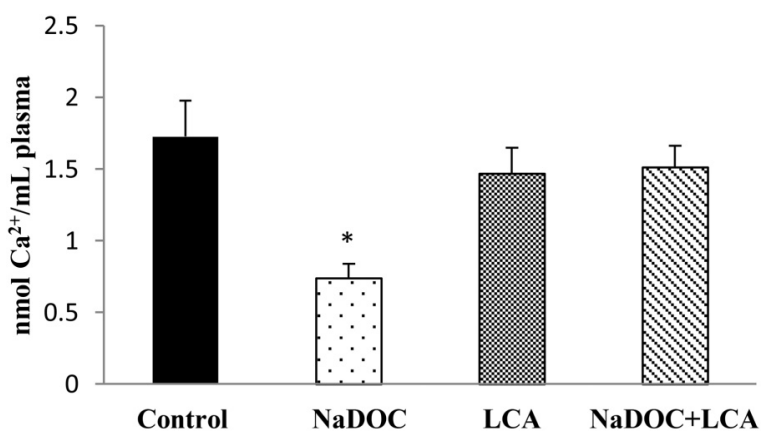

Fig. 2. The effect of different treatments on AP activity. After $30 \mathrm{~min}$ of injecting $0.2 \mathrm{mmol} / \mathrm{L} \mathrm{LCA}, 10 \mathrm{mmol} / \mathrm{L} \mathrm{NaDOC}, 0.2 \mathrm{mmol} / \mathrm{L}$ $\mathrm{LCA}+10 \mathrm{mmol} / \mathrm{L} \mathrm{NaDOC}$, or vehicle into the duodenal sac, AP activity was measured in water homogenates $(1: 10 \mathrm{w} / \mathrm{v})$ of intestinal mucosa using $p$-nitrophenyl phosphate as substrate in $0.5 \mathrm{~mol} / \mathrm{L}$ diethanolamine buffer; $\mathrm{pH} 9.8$. Values are the mean \pm SE: Control $(n=5$ chicks); NaDOC ( $n=7$ chicks); LCA ( $n=6$ chicks); NaDOC + LCA $(n=6$ chicks); ${ }^{*}, p<0.05$ compared with the control, LCA, and NaDOC + LCA treatment groups.

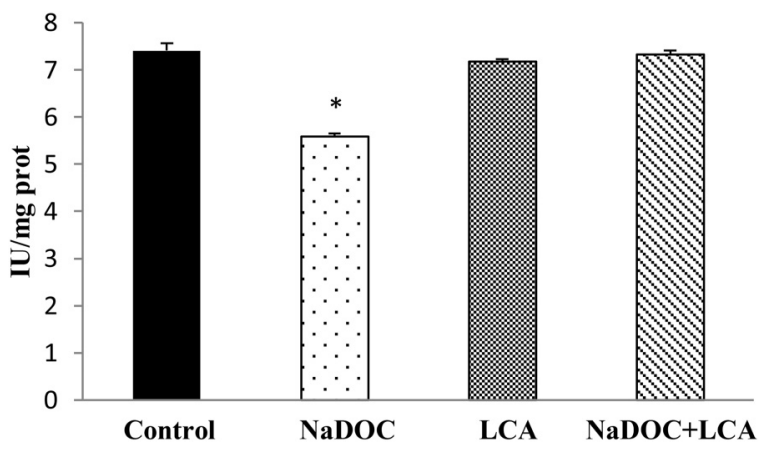

LCA blocked a decrease caused by NaDOC on gene and protein expression of molecules involved in the transcellular pathway of intestinal $\mathrm{Ca}^{2+}$ absorption

Gene expressions of $C B D_{28 k}, P M C A_{1 b}$, and NCX1 were decreased by NaDOC treatment. These changes were avoided with the co-treatment of LCA, and LCA alone did not produce any alteration (Figs. 3A, 3B, and 3C). Similarly, the protein expressions of CB $\mathrm{D}_{28 \mathrm{k}}, \mathrm{PMCA}_{1 \mathrm{~b}}$, and NCX1 were decreased by NaDOC treatment; LCA did not affect them but it aborted the inhibitory effect of NaDOC (Figs. 4A, 4B, and 4C).

The oxidative stress triggered by NaDOC was avoided by simultaneous treatment with LCA

As can be seen on Fig. 5A, the intestinal protein carbonyl content was increased by NaDOC, remained unchanged with LCA, and was identical to that of the control group when animals were treated with NaDOC and LCA at the same time. A similar response was obtained when the production of $\cdot \mathrm{O}_{2}^{-}$was analyzed after the single or simultaneous treatment with NaDOC and (or) LCA (Fig. 5B). 
Fig. 3. qRT-PCR analysis of chick duodenal mucosa mRNA expression levels of $C B D_{28 k}(\mathrm{~A}), P M C A_{1 b}$ (B), and $N C X 1$ (C). Gene expression levels after $30 \mathrm{~min}$ of treatment represent the relative mRNA expression compared with the $18 \mathrm{~S} \mathrm{mRNA}$. Values are the mean \pm SE from 5 chicks for each experimental condition; * $p<0.05$ compared with the control, LCA, and NaDOC + LCA treatment groups.
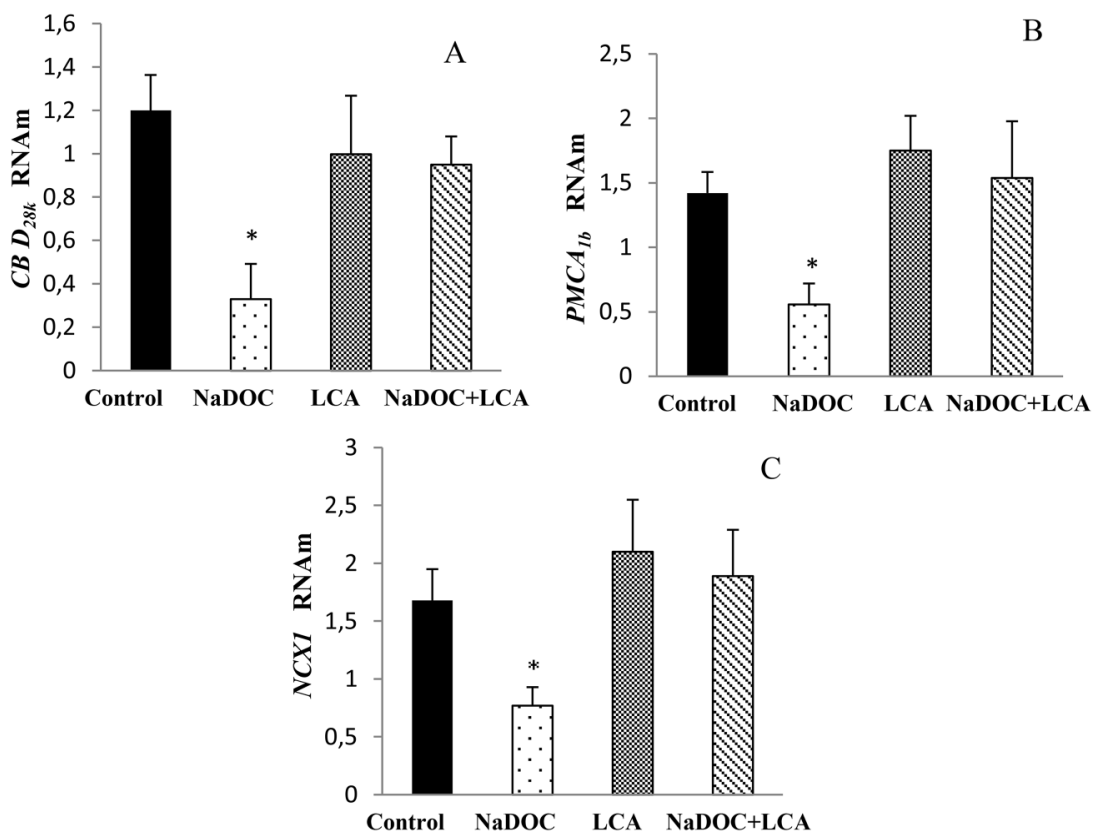

Fig. 4. Effect of different treatments on the protein expression of $C B D_{28 k}, P_{M C A}$, and NCX1. After 30 min of injecting $0.2 \mathrm{mmol} / \mathrm{L}$ LCA, $10 \mathrm{mmol} / \mathrm{L}$ $\mathrm{NaDOC}, 0.2 \mathrm{mmol} / \mathrm{LCA}+10 \mathrm{mmol} / \mathrm{L} \mathrm{NaDOC}$, or vehicle, the protein expression of $\mathrm{CB}_{28 \mathrm{k}}(\mathrm{A}), \mathrm{PMCA}_{1 \mathrm{~b}}(\mathrm{~B})$, and NCX1 (C) was analyzed by Western blot in pool of mucosa from 3 chick duodena for each experimental condition. One hundred micrograms of duodenal mucosa homogenate suspension was separated by SDS-PAGE and immunoblotted with the corresponding antibodies, followed by detection with DAB as a chromogen. Three independent experiments were accomplished. Values are the mean $\pm \mathrm{SE}$; *, $p<0.05$ compared with the control, LCA, and NaDOC + LCA treatment groups.
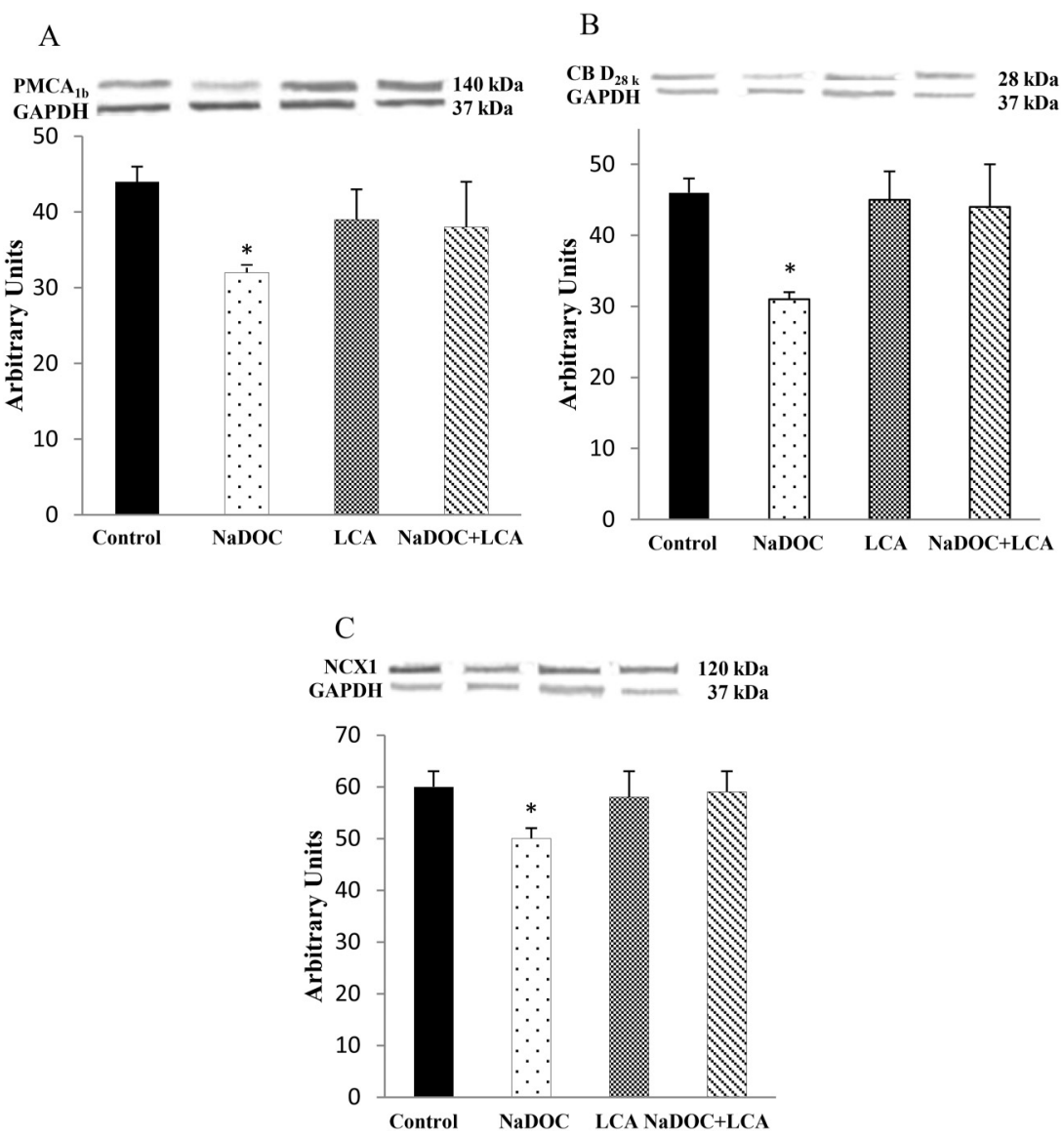
Fig. 5. The effect of different treatments on protein carbonyl content (A) and production of superoxide anion ( $\left(\mathrm{O}_{2}^{-}\right)(\mathrm{B})$. After $30 \mathrm{~min}$ of injecting $0.2 \mathrm{mmol} / \mathrm{L} \mathrm{LCA}, 10 \mathrm{mmol} / \mathrm{L} \mathrm{NaDOC}, 0.2 \mathrm{mmol} / \mathrm{L} \mathrm{LCA}+10 \mathrm{mmol} / \mathrm{L} \mathrm{NaDOC}$, or vehicle into the duodenal sac, the protein carbonyl content and $\cdot \mathrm{O}_{2}^{-}$were measured. Values are the mean $\pm \mathrm{SE}$ from 5 chicks for each experimental condition; ${ }^{*}, p<0.05$ compared with the control, LCA, and NaDOC + LCA treatment groups.
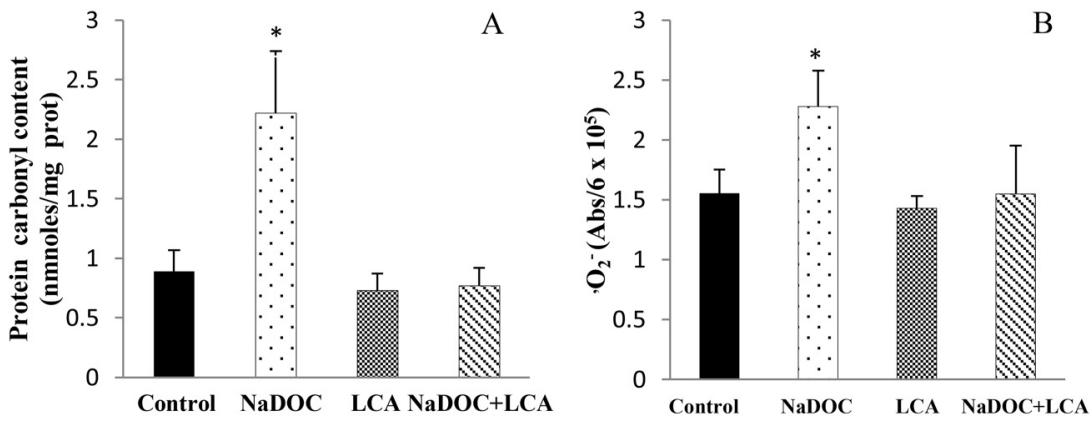

LCA ameliorated the changes in mitochondrial membrane permeability (swelling) provoked by NaDOC

Mitochondrial swelling due to alterations in mitochondrial permeability was monitored through changes in the absorbance of mitochondrial suspensions at $540 \mathrm{~nm}$. Freshly isolated mitochondria of duodenal mucosa from control chicks were exposed to NaDOC $(1 \mathrm{mmol} / \mathrm{L})$, LCA $(0.2 \mathrm{mmol} / \mathrm{L})$, or to both BAs $(1 \mathrm{mmol} / \mathrm{L}$ NaDOC plus $0.2 \mathrm{mmol} / \mathrm{L}$ LCA) at the same time. As expected, NaDOC produced a sharp decrease in the absorbance after addition to the mitochondrial incubation. LCA caused a lower decrease in the absorbance of the mitochondrial suspensions, and the cotreatment partially prevented the intense alteration in the absorbance produced by NaDOC (Fig. 6).

The extrinsic pathway of apoptosis was triggered by NaDOC in chick duodenal mucosa, which was abrogated by LCA cotreatment

The protein expression of FAS and FASL, two molecules involved in the extrinsic route of apoptosis, was significantly increased by NaDOC. In contrast, LCA by itself had no effect on that pathway. However, LCA blocked the effect of NaDOC when both drugs were administered simultaneously (Fig. 7). The activity of caspase-3, one of the main executioners of apoptosis, was also increased by NaDOC. LCA alone did not modify the enzyme activity but avoided the enhancement caused by NaDOC.

\section{Discussion}

This study clearly shows that LCA protects intestinal $\mathrm{Ca}^{2+} \mathrm{ab}-$ sorption under conditions of oxidative stress. However, LCA does not affect intestinal $\mathrm{Ca}^{2+}$ absorption in the chick when enterocytes exhibit a physiological redox state. This response is unique in comparison with other BAs. As previously mentioned, NaDOC inhibits intestinal $\mathrm{Ca}^{2+}$ absorption, which occurs in the range of concentrations typically found in the aqueous phase of stool in patients with ileal resection (Hofmann and Hoffman 1974). By comparison, UDCA stimulates intestinal $\mathrm{Ca}^{2+}$ absorption either in chicks or rats, and in addition, UDCA avoids the inhibitory effect of NaDOC when both are administered simultaneously (Rodríguez et al. 2013). In other words, the single administration of NaDOC, UDCA, or LCA has different effects on intestinal $\mathrm{Ca}^{2+}$ transport. The inhibitory effect of NaDOC seems to be a result of the intracellular oxidative stress, apoptosis, and (or) autophagy occurring in the enterocytes. As the activity of AP declines after NaDOC treatment as well as the protein expression of molecules involved in the cation movement from the enterocytes towards the lamina propria such as PMCA1b, NCX1, and CB $\mathrm{D}_{28 \mathrm{k}}$, it can be assumed that the transcellular pathway of intestinal $\mathrm{Ca}^{2+}$ absorption is damaged by NaDOC. By comparison, UDCA per se increases intestinal $\mathrm{Ca}^{2+}$ absorption, improving the transcellular $\mathrm{Ca}^{2+}$ transport without altering the intestinal redox state. Apparently, this effect

Fig. 6. Optical density changes (swelling) in mitochondria isolated from chick enterocytes. Basal values of mitochondrial absorbance were measured for $5 \mathrm{~min}$ (control) and optical density was followed for 5 more minutes after the addition of $0.2 \mathrm{mmol} / \mathrm{L} \mathrm{LCA}, 1 \mathrm{mmol} / \mathrm{L}$ $\mathrm{NaDOC}, 1 \mathrm{mmol} / \mathrm{L} \mathrm{NaDOC}+0.2 \mathrm{mmol} / \mathrm{L} \mathrm{LCA}$, or vehicle. The arrow indicates the addition of the treatment. The graph represents one of 3 separate experiments.

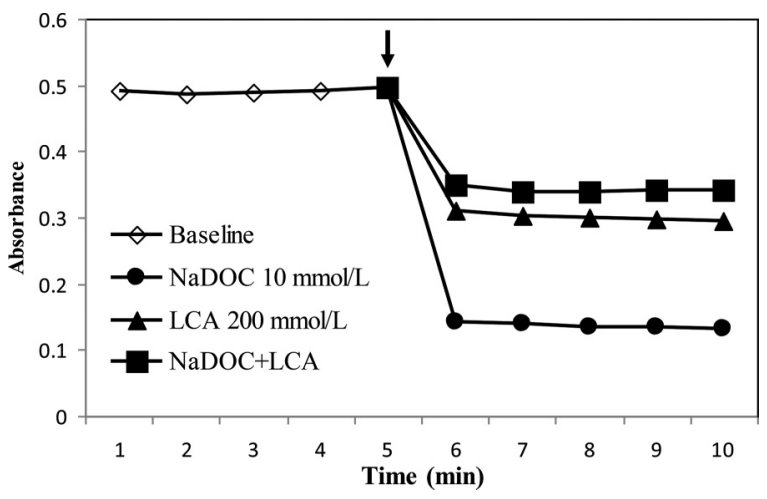

could be a consequence of enhancing VDR protein expression. This work demonstrates that neither the intestinal $\mathrm{Ca}^{2+}$ absorption nor the redox state of enterocytes is changed by LCA alone. In agreement, no increase in serum Ca was found when very high levels of LCA were given to vitamin D-sufficient rats, presumably because $1,25(\mathrm{OH})_{2} \mathrm{D}_{3}$ is a more potent VDR ligand compared with the low affinity of LCA (Nehring et al. 2007). Therefore, NaDOC, UDCA, and LCA trigger different mechanisms in the chick duodenum, which suggests that global intestinal $\mathrm{Ca}^{2+}$ absorption under physiological conditions will depend on the proportion of each BA in the bile flowing into the enteric fluid. Whether the chemical structure, the degree of solubility, the receptors which they bind to, or other factors are responsible for the variety of intestinal responses to these BAs remains unanswered.

LCA does not alter the gene and protein expression of molecules presumably involved in the transcellular pathway, which correlates with the lack of effect of LCA on the intestinal $\mathrm{Ca}^{2+}$ absorption. However, Nehring et al. (2007) have found that LCA increased the expression of TRPV6, calbindin $\mathrm{D}_{9 \mathrm{k}}$, and $\mathrm{Ca}^{2+}$-ATPase mRNA in the intestine of male vitamin D-deficient mice. As the authors suggest, perhaps LCA can act as a vitamin D substitute only in vitamin D deficient states, because LCA does not compete with any VDR ligand. Furthermore, it has been suggested that LCA may induce a VDR conformation distinct from $1,25(\mathrm{OH})_{2} \mathrm{D}_{3}$, exhibiting selective physiological functions (Adachi et al. 2005). Although LCA does not modify the gene and protein expression of molecules involved in the $\mathrm{Ca}^{2+}$ transport, it avoids the inhibitory effects of 
Fig. 7. The effect of different treatments on the protein expression of FAS (A) and FASL (B) and caspase-3 activity (C). After 30 min of injecting $0.2 \mathrm{mmol} / \mathrm{L} \mathrm{LCA}, 10 \mathrm{mmol} / \mathrm{L} \mathrm{NaDOC}, 0.2 \mathrm{mmol} / \mathrm{L} \mathrm{LCA}+10 \mathrm{mmol} / \mathrm{L} \mathrm{NaDOC}$, or vehicle into the duodenal sac, the protein expression of FAS and FASL was analyzed by Western blot in a pool of mucosa. Caspase-3 activity measurements were accomplished at $405 \mathrm{~nm}$ on supernatant from the homogenates of enterocytes. Values are the mean \pm SE. Each value corresponds to a pool of 3 or 4 intestines. Values for the mean are from 4 different measurements; ${ }^{*}, p<0.05$ compared with the control, LCA, and NaDOC + LCA treatment groups.

A
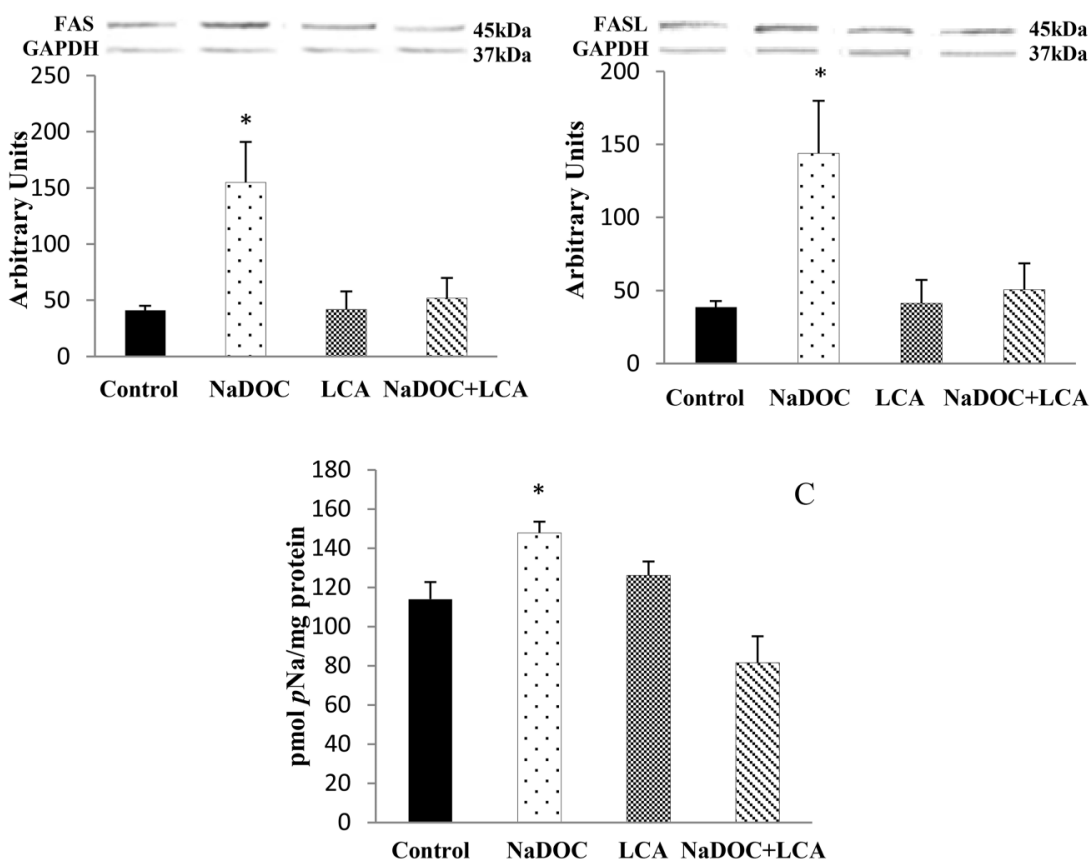

NaDOC on $\mathrm{PMCA}_{1 \mathrm{~b}}$, NCX1, and $\mathrm{CB} \mathrm{D}_{28 \mathrm{k}}$ expressions. The protective action of LCA is apparently related to the blockage of oxidative stress, as judged by its abolition of the enhancement of $\cdot \mathrm{O}_{2}^{-}$and carbonyl groups and the mitochondrial swelling caused by NaDOC.

As is known, oxidative stress could easily lead to cell death by apoptosis (Kannan and Jain 2000). In fact, we have previously demonstrated that the intrinsic pathway of apoptosis is triggered by NaDOC (Rivoira et al. 2012). Our data showing the enhancement in the protein expression of FAS, FASL, and in caspase-3 activity indicate that the extrinsic pathway is also involved in the apoptosis caused by NaDOC. In contrast, LCA does not affect the apoptotic extrinsic pathway but avoids the enhancement of FASFASL-caspase-3 caused by NaDOC when it is administered simultaneously.

The intriguing point is that the combinations of NaDOC-UDCA or NaDOC-LCA all block the inhibitory effect of NaDOC on intestinal $\mathrm{Ca}^{2+}$ absorption. The beneficial effect of UDCA would be through the enhancement of VDR, which could trigger the activation of molecules involved in the intestinal $\mathrm{Ca}^{2+}$ movement. Some studies suggest that LCA induces its own detoxification by activating nuclear receptors to promote transcription of genes encoding sulfotransferase, and it is suggested that LCA not only may undergo sulfation, but that it is also effluxed back into the intestinal lumen (Hofmann 2004). The efficiency in LCA detoxification could explain the lack of effect of LCA alone on the intestine but not the mechanism of protection of LCA against the inhibitory effect of $\mathrm{NaDOC}$ on the intestinal $\mathrm{Ca}^{2+}$ absorption. Another aspect to take into account is the possibility that LCA could bind to other receptors in the intestine, such as FXR and PXR. Although LCA seems to bind modestly to FXR, FXR activation is known to induce the genes involved in enteroprotection (Inagaki et al. 2006). With respect to PXR, it is more confusing, because Owen et al. (2010), based on the different intestinal responses according to the route of administration of LCA, have suggested that in the intestine, the structure of LCA may be altered and that it is no longer a ligand for PXR. Beyond that, BAs are known to provoke also non-receptormediated effects (Katona et al. 2009).

In conclusion, LCA in the intestinal lumen protects the absorption of intestinal $\mathrm{Ca}^{2+}$ from the inhibitory effects of NaDOC. LCA avoids the reduction of the transcellular $\mathrm{Ca}^{2+}$ movement by blocking the oxidative stress and apoptosis triggered by NaDOC, normalizing the gene and protein expression of molecules involved in the $\mathrm{Ca}^{2+}$ movement from lumen to blood. Since the functional toxicity of LCA in humans is in question due to the efficient human detoxification (Hofmann 2004), the use of LCA or derivatives to protect the intestinal $\mathrm{Ca}^{2+}$ absorption under oxidant conditions caused by medications or pathological conditions, e.g., diabetes mellitus or gut inflammation, might become a possible treatment.

\section{Acknowledgements}

This work was supported by Grants from CONICET (PIP 2013), Ministerio de Industria, Comercio, Minería y Desarrollo Científico Tecnológico de la Provincia de Córdoba (PID 2010) and SECYT (UNC), Argentina. Prof. Dr. Nori Tolosa de Talamoni and Dr. Valeria Rodríguez are Members of Investigator Career from the Consejo Nacional de Investigaciones Científicas y Tecnológicas (CONICET). All of the authors participated in the conception, design, and performance of the study as well as interpretation of data and drafting the manuscript. None of the authors had a personal conflict of interest associated with this work.

\section{References}

Adachi, R., Honma, Y., Masuno, H., Kawana, K., Shimomura, I., Yamada, S., and Makishima, M. 2005. Selective activation of vitamin D receptor by lithocholic acid acetate, a bile acid derivative. J. Lipid Res. 46(1): 46-57. PMID:15489543.

Arlia-Ciommo, A., Piano, A., Svistkova, V., Mohtashami, S., and Titorenko, V.I. 2014. Mechanisms underlying the anti-aging and anti-tumor effects of lithocholic bile acid. Int. J. Mol. Sci. 15(9): 16522-16543. doi:10.3390/ijms150916522. PMID:25238416. 
Banerjee, S., Trivedi, G.K., Srivastava, S., and Phadke, R.S. 1993. Proxyl nitroxide of lithocholic acid: a potential spin probe for model membranes. Bioorg. Med. Chem. 1(5): 341-347. doi:10.1016/S0968-0896(00)82140-9. PMID:8081864.

Centeno, V.A., Díaz de Barboza, G.E., Marchionatti, A.M., Alisio, A.E., Dallorso, M.E., Nasif, R., and Tolosa de Talamoni, N.G. 2004. Dietary calcium deficiency increases $\mathrm{Ca}^{2+}$ uptake and $\mathrm{Ca}^{2+}$ extrusion mechanisms in chick enterocytes. Comp. Biochem. Physiol., Part A: Mol. Integr. Physiol. 139(2): 133-141. doi:10.1016/j.cbpb.2004.08.002. PMID:15528161.

Dang, Z., Lin, A., Ho, P., Soroka, D., Lee, K.H., Huang, L., and Chen, C.H. 2011 Synthesis and proteasome inhibition of lithocholic acid derivatives. Bioorg. Med. Chem. Lett. 21(7): 1926-1928. doi:10.1016/j.bmcl.2011.02.041. PMID:21388808.

do Nascimento, P.G., Lemos, T.L., Almeida, M.C., de Souza, J.M., Bizerra, A.M., Santiago, G.M., et al. 2015. Lithocholic acid and derivatives: antibacterial activity. Steroids, 104: 8-15. doi:10.1016/j.steroids.2015.07.007. PMID:26216208.

Garcia-Calvo, M., Peterson, E.P., Leiting, B., Ruel, R., Nicholson, D.W., and Thornberry, N.A. 1998. Inhibition of human caspases by peptide-based and macromolecular inhibitors. J. Biol. Chem. 273(49): 32608-32613. doi:10.1074/ jbc.273.49.32608. PMID:9829999.

Halvorsen, B., Staff, A.C., Ligaarden, S., Prydz, K., and Kolset, S.O. 2000. Lithocholic acid and sulphated lithocholic acid differ in the ability to promote matrix metalloproteinase secretion in the human colon cancer cell line CaCo-2. Biochem. J. 349(1): 189-193. doi:10.1042/0264-6021:3490189. PMID: 10861227.

Hofmann, A.F. 2004. Detoxification of lithocholic acid, a toxic bile acid: relevance to drug hepatotoxicity. Drug Metab. Rev. 36(3-4): 703-722. doi:10.1081/ DMR-200033475. PMID:15554243.

Hofmann, A.F., and Hoffman, N. 1974. Measurement of bile and acid kinetics by isotope dilution in man. Gastroenterology, 67(2): 314-323. PMID:4603252.

Hylemon, P.B., Zhou, H., Pandak, W.M., Ren, S., Gil, G., and Dent, P. 2009. Bile acids as regulatory molecules. J. Lipid Res. 50(8): 1509-1520. doi:10.1194/jlr. R900007-JLR200. PMID:19346331.

Inagaki, T., Moschetta, A., Lee, Y.K., Peng, L., Zhao, G., Downes, M., et al. 2006. Regulation of antibacterial defense in the small intestine by the nuclear bile acid receptor. Proc. Natl. Acad. Sci. U.S.A. 103(10): 3920-3925. doi:10.1073/pnas. 0509592103. PMID:16473946.

Ishizawa, M., Matsunawa, M., Adachi, R., Uno, S., Ikeda, K., Masuno, H., et al 2008. Lithocholic acid derivatives act as selective vitamin D receptor modulators without inducing hypercalcemia. J. Lipid. Res. 49(4): 763-772. doi:10. 1194/jlr.M700293-JLR200. PMID:18180267.

Kannan, K., and Jain, S. 2000. Oxidative stress and apoptosis. Pathophysiology, 7(3): 153-163. doi:10.1016/S0928-4680(00)00053-5. PMID:10996508.

Katona, B.W., Anant, S., Covey, D.F., and Stenson, W.F. 2009. Characterization of enantiomeric bile acid-induced apoptosis in colon cancer cell lines. J. Biol. Chem. 284: 3354-3364. doi:10.1074/jbc.M805804200. PMID:19054763.

Laemmli, U.K. 1970. Cleavage of structural proteins during the assembly of the head of bacteriophage T4. Nature, 227(5259): 680-685. doi:10.1038/227680a0. PMID:5432063.

zsn>Levine, R.L., Garland, D., Oliver, C.N., Amici, A., Climent, I., Lenz, A.G., et al. 1990. Determination of carbonyl content in oxidatively modified proteins. In Oxygen radicals in biological systems, part B: oxygen radicals and antioxidants. Vol. 186 of Methods in enzymology. pp. 464-478. doi:10.1016/00766879(90)86141-H. PMID:1978225.

Livak, K.J., and Schmittgen, T.D. 2001. Analysis of relative gene expression data using real-time quantitative PCR and the 2-DDCT method. Methods, 25(4): 402-408. doi:10.1006/meth.2001.1262. PMID:11846609.

Makishima, M., Lu, T.T., Xie, W., Whitfield, G.K., Domoto, H., Evans, R.M., et al.
2002. Vitamin D receptor as an intestinal bile acid sensor. Science, 296(5571): 1313-1316. doi:10.1126/science.1070477. PMID:12016314.

Marchionatti, A., Alisio, A., Díaz de Barboza, G., Baudino, V., and Tolosa de Talamoni, N. 2001. DL-Buthionine-S, R-sulfoximine affects intestinal alkaline phosphatase activity. Comp. Biochem. Physiol., Part C: Toxicol. Pharmacol. 129(2): 85-91. doi:10.1016/S1532-0456(01)00185-5.

Masubuchi, N., Sugihara, M., Sugita, T., Amano, K., Nakano, M., and Matsuura, T. 2016. Oxidative stress markers, secondary bile acids and sulfated bile acids classify the clinical liver injury type: Promising diagnostic biomarkers for cholestasis. Chem.-Biol. Interact. 255: 83-91. doi:10.1016/j.cbi.2015.08.016. PMID:26325587.

Nehring, J.A., Zierold, C., and DeLuca, H.F. 2007. Lithocholic acid can carry out in vivo functions of vitamin D. Proc. Natl. Acad. Sci. U.S.A. 104(24): 10006-10009. doi:10.1073/pnas.0703512104. PMID:17535892.

Owen, B.M., Milona, A., van Mil, S., Clements, P., Holder, J., Boudjelal, M., et al. 2010. Intestinal detoxification limits the activation of hepatic pregnane $X$ receptor by lithocholic acid. Drug Metab. Dispos. 38(1): 143-149. doi:10.1124/ dmd.109.029306. PMID:19797606.

Rivoira, M.A., Marchionatti, A.M., Centeno, V.A., Díaz de Barboza, G.E., Peralta López, M.E., and Tolosa de Talamoni, N.G. 2012. Sodium deoxycholate inhibits chick duodenal calcium absorption through oxidative stress and apoptosis. Comp. Biochem. Physiol., Part A: Mol. Integr. Physiol. 162(4): 397405. doi:10.1016/j.cbpa.2012.04.016. PMID:22561666.

Rodrigues, C.M., Fan, G., Wong, P.Y., Kren, B.T., and Steer, C.J. 1998. Ursodeoxycholic acid may inhibit deoxycholic acid-induced apoptosis by modulating mitochondrial transmembrane potential and reactive oxygen species production. Mol. Med. 4(3): 165-178. PMID:9562975.

Rodríguez, V., Rivoira, M., Marchionatti, A., Pérez, A., and Tolosa de Talamoni, N. 2013. Ursodeoxycholic and deoxycholic acids: A good and a bad bile acid for intestinal calcium absorption. Arch. Biochem. Biophys. 540(1-2): 19-25. doi:10. 1016/j.abb.2013.09.018. PMID:24096173.

Rodríguez, V.A., Rivoira, M.A., Pérez, A.V. Marchionatti, A.M., and Tolosa de Talamoni, N.G. 2016. Ursodeoxycholic and deoxycholic acids: Differential effects on intestinal $\mathrm{Ca}^{2+}$ uptake, apoptosis and autophagy of rat intestine. Arch. Biochem. Biophys. 591: 28-34. doi:10.1016/j.abb.2015.12.006. PMID:26707246.

Schneider, H., Fiander, H., Harrison, K.A., Watson, M., Burton, G.W., and Arya, P. 1996. Inhibitory potency of lithocholic acid analogs and other bile acids on glucuronosyltransferase activity in a colon cancer cell line. Bioorg. Med. Chem. Lett. 6(6): 637-642. doi:10.1016/0960-894X(96)00092-3.

Serrander, L., Cartier, L., Bedard, K., Banfi, B., Lardy, B., Plastre, O., et al. 2007. NOX4 activity is determined by mRNA levels and reveals a unique pattern of ROS generation. Biochem. J. 406(1): 105-114. doi:10.1042/BJ20061903. PMID: 17501721.

Tolosa de Talamoni, N., Pereira, R., de Bronia, D.H., Moreno, J., and Cañas, F. 1985. Phospholipids and sialic acid changes produced by vitamin D3 on intestinal mitochondria. Metabolism, 34(11): 1007-1011. doi:10.1016/0026-0495 (85)90071-X. PMID:2997574.

Tolosa de Talamoni, N., Marchionatti, A., Baudino, V., and Alisio, A. 1996. Glutathione plays a role in the chick intestinal calcium absorption. Comp. Biochem. Physiol. A Physiol. 115(2): 127-132. doi:10.1016/0300-9629(96)00023-0. PMID: 8916550.

Towbin, H., Staehelin, T., and Gordon, J. 1979. Electrophoretic transfer of proteins from polyacrylamide gels to nitrocellulose sheets: procedure and some applications. Proc. Natl. Acad. Sci. U.S.A. 76(9): 4350-4354. doi:10.1073/pnas. 76.9.4350. PMID:388439. 